INTERNATIONAL JOURNAL OF RESEARCHES IN BIOSCIENCES, AGRICULTURE AND TECHNOLOGY (C) VISHWASHANTI MULTIPURPOSE SOCIETY (Global Peace Multipurpose Society) R. No. MH-659/13(N) www.vmsindia.org

\title{
STUDIES ON THE CYTOLOGICAL CHANGES IN THE VITELLOGENIC STAGES OF OOGENESIS IN THE DEVELOPING OVARY OF OTHREIS MATERNA (LEPIDOPTERA: NOCTUIDAE)
}

\author{
A. S. Mohite and A. V. Dorlikar \\ P.G. Department of Zoology and Research Academy, Sevadal College for Women, Nagpur-India \\ anil.mohite64@gmail.com
}

\begin{abstract}
:
In Othreis materna, vitellogenesis commences just after emergence of the moth and terminates in the seven day old moth. During vitellogenesis the developing oocytes showed marked changes in their shape, size and cytological organization. Developmental of terminal oocytes has been divided into five stages: the pre-vitellogenic, the early vitellogenic, the vitellogenic, the late vitellogenic and maturation stage. Day wise histological and cytological changes in the nurse cells, follicular epithelial cells and the size of terminal oocyte follicle have been studied. The average length and width of terminal oocyte follicles of last day pupa to seventh day old adult female were ranged from $142.10 \hat{\mathrm{A}} \pm 2.3$ to $621.20 \hat{\mathrm{A}} \pm 6.9 \hat{\mathrm{I}} 1 / 4 \mathrm{~m}$ and $110.60 \hat{\mathrm{A}} \pm 0.82$ to $633.00 \hat{\mathrm{A}} \pm 2.9 \hat{\mathrm{I}} 1 / 4 \mathrm{~m}$, respectively. Wight of the ovary during the process of vitellogenesis was found to be $91.00 \hat{\mathrm{A}} \pm 2.0 \mathrm{mg}$ in last day of pupa to $374.00 \mathrm{~A} \pm 11.7$ $\mathrm{mg}$ in seventh day old female moth.

Keywords: Fruit Piercing Moths, Genus Othreis, oocyte development, vitellogenesis
\end{abstract}

\section{Introduction:}

The fruit piercing moths of Genus Othreis (Eudocima) have attained great importance amongst Noctuidae because of their notorious habits. They are serious pests of fruit crops throughout tropical and subtropical belt from Africa to Southeast Asia and Australia to the Pacific Islands (BÃanziger, 1982; Waterhouse and Norris, 1987). The anatomical organization, morphology and histology of female reproductive system of adult lepidopteran insects have been described in a number of species (Buntin and Pedigo, 1983; Lingren et al., 1987; Yel and Eren, 2000). The oocyte development and vitellogenesis are also studied well by various researchers (Kawooya et al., 1986; Santos and Gregoria, 2000 and Xinquaun et al., 2004). $\mathrm{N}$ attempt has been made to study the histological changes occurring in the developing oocytes of fruit sucking moth Othreis materna.

\section{Material and Methods:}

Adult fruit-sucking moths of Othreis materna were collected at night from the citrus orchards of different places of Vidarbha region of Maharashtra state with the help of hand nets. The laboratory culture was maintained at room temperature (22-24oC) and relative humidity $(60-65 \%)$. Adults were kept in specially prepared cages provided with fine wire nets from the sides. The adult moths were fed with ripen oranges (when available) or $10 \%$ sucrose solution and honey mixture (3:1). For rearing of the larvae, plastic trays were used. The adult females developed from pupae were separated from the males on the basis of broad abdomen. The female reproductive system was dissected out on every day since emergence till the control moths undergo oviposition, i.e. Seventh day. The ovaries were fixed in aqueous Bouinâ€ $€^{\mathrm{TM}} \mathrm{S}$ fluid for 18 â€“ 24 hours, washed, dehydrated, cleared in xylene and embedded in paraffin wax (600c). Sections were cut at $4 \hat{\text { Âm }}$ thickness and stained with either Haematoxylin-Eosin or Iron-Haematoxylin staining techniques (Humason, 1962). Histological sections were examined by Labomed Digi-3 compound microscope.

\section{Result and Discussion}

The process of oogenesis is often evident in the terminal oocyte of the ovariole of the ovary of insect (Figure. 1). During vitellogenesis the developing oocytes show marked changes in their shape, size and cytological organization. Vitellogenesis takes place through five consecutive vitellogenic stages; pre-vitellogenic, early vitellogenic, vitellogenic, late vitellogenic and maturation. The terminal oocyte follicle of eight day old pupa consist of a group of seven nurse cells dorsally and an oocyte ventrally (Figure. 2A ). The oocyte bears a centrally placed large germinal vesicle. The terminal oocyte follicle of last day pupa measures about 142.10

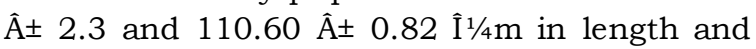
width respectively. The ovaries of last day old pupa weigh about $91.00 \hat{\mathrm{A}} \pm 2.0 \mathrm{mg}$. The terminal oocyte gradually enlarges in size from one day old female to seven day old female. The terminal follicles of first day to seven day old females measures about 181.50 Ât 3.9, 283.30 $\hat{\mathrm{A}} \pm$ 3.6, 458.20 $\hat{\mathrm{A}} \pm$ 3.9, $489.90 \hat{\mathrm{A}} \pm 6.9,523.70 \hat{\mathrm{A}} \pm$ 5.7, 574.30 $\hat{\mathrm{A}} \pm 2.9,621.20 \hat{\mathrm{A}} \pm 6.9 \hat{\mathrm{I}} 1 / 4 \mathrm{~m}$ and $158.00 \hat{\mathrm{A}} \pm 1.50,242.40 \hat{\mathrm{A}} \pm 1.30,331.80 \hat{\mathrm{A}} \pm$ 2.80, $401.00 \hat{\mathrm{A}} \pm 2.10,454.40 \hat{\mathrm{A}} \pm 2.10,563.00$ 
$\hat{\mathrm{A}} \pm 2.50,633.00 \hat{\mathrm{A}} \pm 2.90 \hat{\mathrm{I}} 1 / 4 \mathrm{~m}$ in length and width respectively (Figure. 3). The ovaries of the first day old female to seven day old females weigh about $123.00 \hat{\mathrm{A}} \pm 2.0,154.30 \hat{\mathrm{A}} \pm$ 5.4,

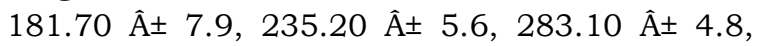
$324.60 \hat{\mathrm{A}} \pm$ 5.7, and 374.60 Â $\pm 5.4 \mathrm{mg}$ respectively (Figure. 4). During early vitellogenic stage the follicular epithelium of Othreis materna showed mitotic activity, but in later stages this was not evident, the follicular epithelial cells are columnar up to first five days. In sixth day old adult terminal oocytes showed columnar epithelial cells over the oocyte and cuboidal over the nurse cells. In maturation stage these cells decreased in height but increased in width (Figs. 2B to 2I), similar changes in the follicular epithelium were also described in D. melanogaster (King and Koch, 1963), Musca domestica (Adams, 1972), L. exigua (Khurad and Thakare, 1980). The follicular epithelial cells in Othreis materna remained uninucleate in all stages as reported in Glossina austeni (Huebner et al., 1975). The growth of oocytes is due to transfer of the cytoplasmic contents from the nurse cells via ring canals to the oocytes. Thus, the nurse cells strongly support oocyte development by contributing cytoplasmic contents (King and Koch, 1963; Yamauchi et al., 1981; Minkenberg, 1985 and Younes et al., 2009). The vitelline membrane and chorion formation in Othreis materna takes place in the maturation stage similar to Cecropia moth (Anderson and telfer, 1969).

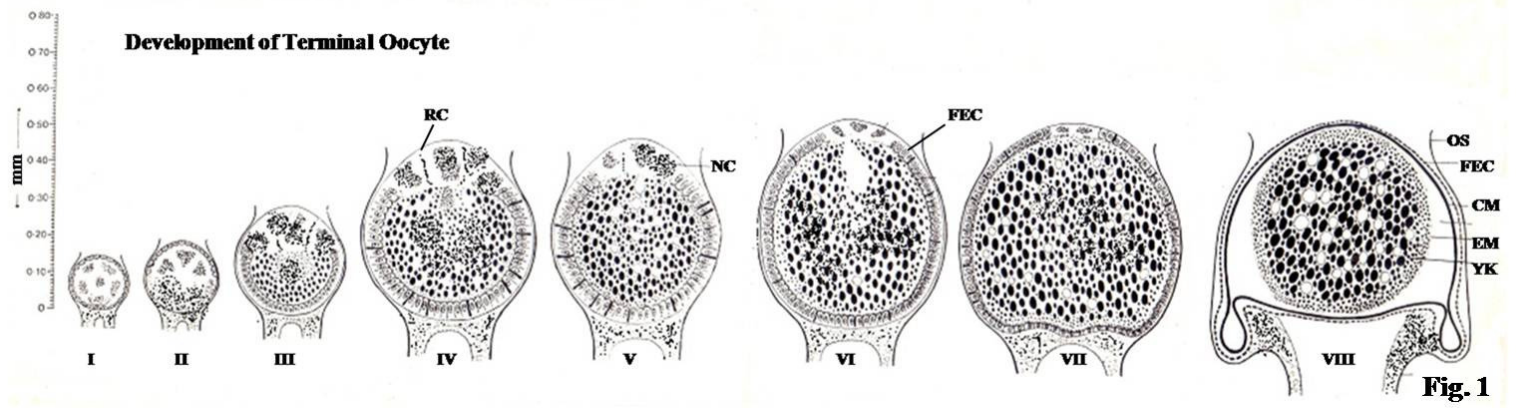

Figure.1. Diagrammatic representation of day-wise development of terminal oocyte follicle CMChorion Membrane, EM- Egg Membrane, FEC- Follicular Epithelial Cells, NC- Nurse Cell, OSPeritonial Sheath, RC- Ring Canal, YK- Yolk.

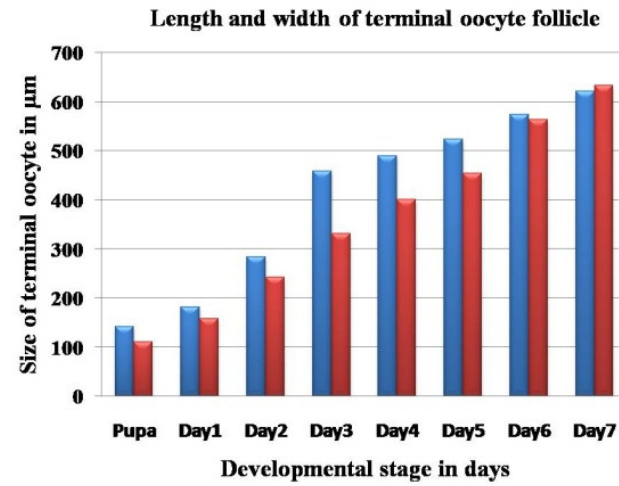

Figure. 3. Length and width of day-wise developing terminal oocyte follicle

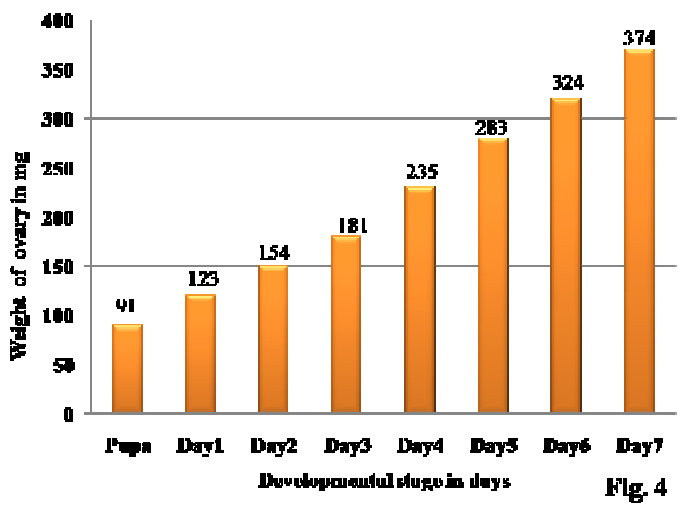

Figure. 4. Weight of ovary of day-wise developing stages of female moth 

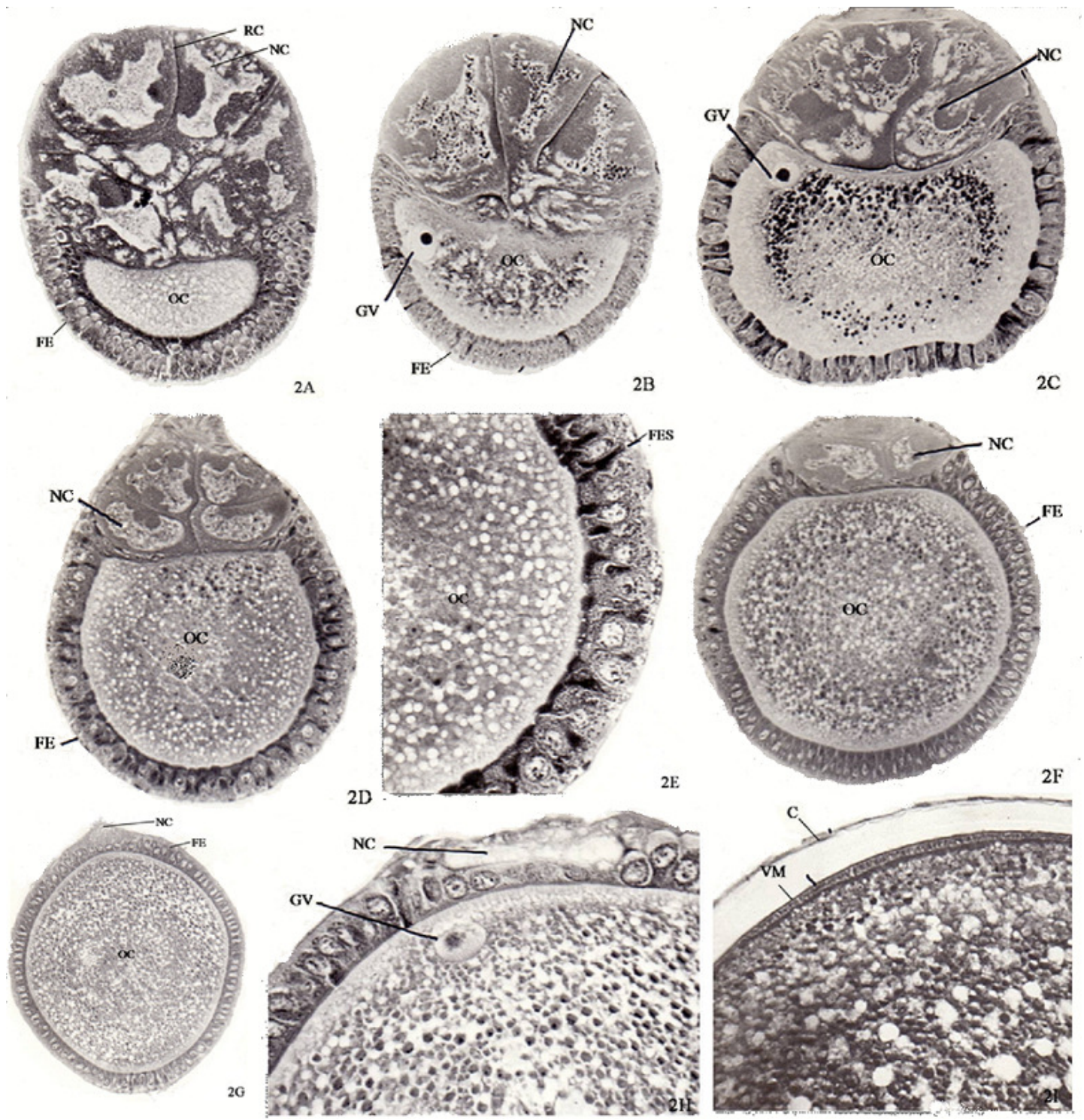

Figure. 2A-2I. Photomicrographs of developing terminal oocyte follicles. (2A) Photomicrograph of previtellogenic oocyte follicle showing large nurse cells and double layer of follicular epithelial cells. (2B) Photomicrograph of early-vitellogenic oocyte follicle showing large nurse cells, double layer of follicular epithelial cells and germinal vesicle. (2C, 2D \& 2E) Photomicrographs of mid-vitellogenic oocyte follicle showing equal size of nurse cells and oocyte, columnar follicular epithelial cells. (2F, 2G \& $2 \mathrm{H})$ Photomicrographs of vitellogenic oocyte follicle showing reduced nurse cells and large oocyte, columnar followed by cuboidal follicular epithelial cells. (2I) Photomicrograph of maturation stage oocyte follicle showing complete degeneration of nurse cells and formation of chorion membrane. CChorion, EM- Egg Membrane, FE- Follicular Epithelium, FES- Follicular Epithelial Space, GVGerminal Vesicle, NC- Nurse Cell, OC-Oocyte, RC- Ring Canal, VM- Vitelline Membrane, YK- Yolk.

\section{Figures legends}

Figure.1. Diagrammatic representation of day-wise development of terminal oocyte follicle CMChorion Membrane, EM- Egg Membrane, FEC- Follicular Epithelial Cells, NC- Nurse Cell, OSPeritonial Sheath, RC- Ring Canal, YK- Yolk.

Figure. 2A-2I. Photomicrographs

\section{Conclusion:}

Histological observations of developing oocytes in Othreis materna reveal that the first vitellogenic cycle exhibits pre vitellogenic period in which oocytes are not clearly differentiated while, one and two day old terminal oocytes exhibit early vitellogenic stage in which the nurse cells and an oocytes grow equally. The accumulation of yolk material occurs during vitellogenic and late vitellogenic stages, when oocytes grow faster and become full of yolk globules. The fast growth of the oocyte during this stage may be due to transfer of cytoplasmic contents from the degenerating nurse cells via ring canals to the oocytes. 


\section{References:}

Adams, T. S., Flint, H. M. and Nelson, D. R. (1972): Effect of X-radiated ovaries on corpus allatum size in the housefly, Musca domestica.J. Insect physiol., 18: 1413-1425.

Anderson, L. M. and Telfer, W. H. (1969): A follicle cell contribution to the yolk spheres of moth oocytes. Tissue and Cell., 1:633-644.

BÃanziger, H. (1982): Fruit-piercing moths (Lepidoptera: Noctuidae) in Thailand: a general survey and new perspectives, Mitteilungen der Schweizerischen Entomologischen Gesellschaft, 55: Pp213-240.

Buntin, G. D. and Pedigo, L. P. (1983): Morphology of the male and female reproductive systems of Plathypena scabra (Fabricius) (Lepidoptera: Noctuidae). J. of Kansas Entomol.Soc., 56 (3): 377-386.

HÃ $1 / 4$ bner, E. Tobe, S. S. Davey, K. G. (1975): Structural and functional dynamics of oogenesis in Glossina austeni: general features, Previtellogenesis and nurse cells. Tissue \& Cell, 7: 297-317.

Kawooya, J. K., Osir, E. O. and Law, J. H. (1986): Physical and chemical properties of microvitellogenin.A protein from the egg of the tobacco hornworm moth, Manduca sexta. J. Biol. Chem.,261: 10844-10849.

Khurad, A. M. and Thakare, V. K. (1980): Cytology and histochemistry of the ovary in the buffalo-fly, Lyperosia exigua (DeMeijere) (Diptera: Muscidae). Int. J. Invert. Reprod., 2(5): 297-310.

King, R. C. and Koch, E. A. (1963): Studies on the ovarian follicle cells of Drosophila melanogaster. Quart. J. Microsc. Sci., 104: 297320.
Lingren, P. D. Henneberry, T. J. and Nelson, R. (1987): Cotton leafperforator (Lepidoptera: Lyonetiidae): Female reproductive system, Male spermatophore and reproductive biology. Ann. Entomol. Soc. Am., 80: 406-410.

Minkenberg, O. P. J. M. and Marc Petit (1985); Ovariole development in workers of Myrmica rubra (Hymenoptera: Formicidae) and its relation to age-polyethism. Am. Soc. R. Zool. Belg., 115(1): 29-44.

Santos, D. C. and Gregoria, E. A. (2002); Ultrastructure of the ovariole sheath in Diatraea saccharalis (Lepidoptera: Pyralidae). Biocell, 26(2): 229-235.

Waterhouse, D.F. and Norris, K.R. (1987): Biological control: pacific prospects, Pp 240249, Inkata Press, Melbourne, Australia, 454p.

Xingquan, K. Calvin, D. D., Knapp, M. C., Poston, F. L. (2004): Female European corn borer (Lepidoptera: Crambidae) Ovarian developmental stages: their association with oviposition and use in a classification system. J. Econ. Entomol., 93(3): 828-835.

Yamauchi, H., Kurihara, M. and Miya, K. (1981): Electron microscope studies on the oogenesis of the silkworm Bombyx mori 4 . Ultrastructural changes of the nurse chamber. J. Fac. Agric. Iwate Univ., 15(3): 155-174.

Yel, M. and Eren, E. (2000): The anatomic and histologic structure of the female reproductive system Pieris rapae (L.) (Lepidoptera: Pieridae). Turk Hijyen Ve Deneysel Biyoloji Dergisi, 51: 2534.

Younes, M. W. F., Shehata, N. F., and Mahmoud, Y.A, (2009): Histopathological effects of gamma irradiation on the peach fruit fly, Bactrocera zonata (Saund.) female gonads. J. Appl. Sci. Res. 1: 305-310. 